\title{
Efektivitas Latihan Incentive Spirometry dengan Latihan Pernapasan Diafragma terhadap Fungsi Paru, Kapasitas Fungsional, dan Kualitas Hidup Penderita Asma Bronkial Alergi
}

\author{
Sitti Nurun Nikmah, Ambrosius Purba, Irma Ruslina Defi \\ Departemen Ilmu Kedokteran Fisik dan Rehabilitasi Fakultas Kedokteran Universitas Padjadjaran \\ Rumah Sakit Dr. Hasan Sadikin Bandung
}

\begin{abstract}
Abstrak
Prevalensi eksaserbasi asma alergi semakin mengalami peningkatan. Berbagai upaya dilakukan untuk dapat menurunkannya, antara lain dengan latihan pernapasan diafragma dan incentive spirometry, namun, perbandingan efektivitas kedua latihan masih belum jelas. Penelitan ini bertujuan untuk mengetahui perbandingan efektivitas kedua latihan tersebut. Penelitian dilakukan di Rumah Sakit Dr. Hasan Sadikin dan Rumah Sakit Paru Dr. H. A. Rotinsulu Bandung (September-Desember 2012). Sejumlah 20 orang perempuan, berusia 26-40 tahun, penderita asma bronkial alergi terkontrol sebagian yang mengikuti penelitian, dibagi ke dalam 2 kelompok. Tiap kelompok diberi latihan incentive spirometry dan pernapasan diafragma selama 8 minggu. Sebelum dan sesudah perlakuan, dilakukan pengukuran fungsi paru dengan forced expiratory volume in 1 second (FEV1), kapasitas fungsional dengan jarak tempuh (uji jalan 6 menit), dan kualitas hidup dengan St George's Respiratory Questionnaire (SGRQ). Karakteristik penderita menunjukkan distribusi normal dan homogen. Uji-t independen menunjukkan bahwa latihan incentive spirometry lebih efektif dibandingkan dengan pernapasan diafragma dalam meningkatkan FEV1 (6,19 $\pm 2,63$ vs $0,40 \pm 0,33 \%$ prediksi), jarak tempuh $(229,07 \pm 21,84$ vs $140,69 \pm 16,91 \mathrm{~m})$ dan memperbaiki SGRQ (nilai total $1.036,51 \pm 341,14$ vs $360,09 \pm 182,10$ ). Simpulan, latihan incentive spirometry lebih efektif dalam meningkatkan fungsi paru, kapasitas fungsional, dan kualitas hidup dibandingkan dengan pernapasan diafragma pada penderita asma bronkial alergi. [MKB. 2014;46(1):39-47]
\end{abstract}

Kata kunci: FEV1, Incentive spirometry, jarak tempuh, latihan pernapasan diafragma, SGRQ

\section{Effectiveness of Incentive Spirometry and Diaphragmatic Breathing Exercise in Lung Function, Functional Capacity and Quality of Life of Bronchial Asthma Allergic Patients}

\begin{abstract}
Exacerbation of allergic asthma prevalence is increasing. Various attempts were made to lower it with diaphragm breathing and incentive spirometry exercise. However, comparison of the effectiveness of both exercises are unclear. This study aims to compare those effects. Research conducted in Dr. Hasan Sadikin General Hospital and Dr. H. A. Rotinsulu Pulmonary Hospital (September-December 2012). Twenty female, aged $26-40$ years, partially controlled bronchial asthma allergic patients who consented for this study were divided into 2 groups. Each group was given incentive spirometry and diaphragm breathing exercise for 8 weeks. Before and after treatment lung function with forced expiratory volume in 1 second - FEV1, functional capacity with walking distance (6 minute walking test) and quality of life (St George's Respiratory Questionnaire-SGRQ) were assessed. The characteristics of the subjects were normally distributed and homogeneous. Independent $\mathrm{T}$ test results showed incentive spirometry compared to diaphragm breathing exercise was more effective in improving FEV1 $(6.19 \pm 2.63$ vs $0.40 \pm 0.33 \%$ predicted), walking distance $(229.07 \pm 21.84$ vs $140.69 \pm 16.91 \mathrm{~m})$, and SGRQ (total value $1,036.51 \pm 341.14$ vs $360.09 \pm 182.10$ ). In conclusion, incentive spirometry is more effective in improving lung function, functional capacity, and quality of life compared to diaphragm breathing exercises in patients with allergic bronchial asthma. [MKB. 2014;46(1):39-47]
\end{abstract}

Key words: Diaphragm breathing exercise, FEV1, incentive spirometry, SGRQ, walking distance

Korespondensi: Sitti Nurun Nikmah, dr., Departemen Ilmu Kedokteran Fisik dan Rehabilitasi Fakultas Kedokteran Universitas Padjadjaran/Rumah Sakit Dr. Hasan Sadikin Bandung, mobile 085355370642, e-mail nikmahadil@gmail.com 


\section{Pendahuluan}

Asma bronkial merupakan penyakit respiratorik kronik yang paling sering ditemukan, berdasarkan penyebabnya dikelompokkan dalam asma alergi dan nonalergi. Asma bronkial diklasifikasikan dalam tiga kelompok berdasarkan level kontrol asma yaitu asma terkontrol penuh, sebagian, dan tidak terkontrol. ${ }^{1}$

Sejak dua dekade terakhir prevalensi asma bronkial meningkat pada orang dewasa, khususnya asma alergi. Prevalensi total asma bronkial di dunia diperkirakan $18 \%$ dari jumlah penderita penyakit paru. Prevalensi asma bronkial sangat bervariasi antarnegara dan di beberapa daerah di suatu negara. World Health Organization (WHO) memperkirakan kematian karena asma bronkial di setiap negara rata-rata sekitar 250.000 setiap tahunnya. ${ }^{1}$ Demikian pula halnya data kunjungan penderita asma bronkial yang berobat ke Rumah Sakit Dr. Hasan Sadikin (RSHS) Bandung tahun 2011 mengalami peningkatan 577 orang, bila dibandingkan dengan tahun 2010 sejumlah 273.

Asma bronkial menunjukkan inflamasi kronik saluran napas yang melibatkan bermacam sel inflamasi dan mediator yang saling berinteraksi sehingga menghasilkan perubahan fisiologis dan struktur jalan napas. Inflamasi kronik tersebut berhubungan dengan hiperresponsif jalan napas yang merujuk pada suatu episode berulang dari mengi, sesak napas, kaku dinding dada, dan juga batuk. Serangan asma ini pada umumnya terjadi pada malam atau pagi hari. Episode berulang mengi dan sesak napas berhubungan dengan luas dan variasi obstruksi jalan napas yang terjadi, umumnya bersifat reversibel baik secara spontan maupun dengan pengobatan. ${ }^{1}$

Pada penderita asma bronkial alergi terjadi proses respons imun berlebihan berupa reaksi hipersensitivitas tipe I. Pada asma bronkial alergi ditemukan respons imun yang dominan yaitu peningkatan pada imunoglobulin $\mathrm{E}(\operatorname{IgE}){ }^{1,2}$ yang sangat spesifik untuk penderita asma bronkial alergi. ${ }^{1,2}$ Untuk membedakan penderita asma dan penyakit paru obstruktif kronik (PPOK) dapat dilaksanakan tes bronkodilator. Apabila dari hasil tes bronkodilator memperlihatkan reversibilitas $>12 \%$ maka penderita termasuk kelompok asma bronkial. ${ }^{1}$ Selain respons imun yang berlebihan pada penderita asma alergi, diperlihatkan juga penurunan fungsi paru, kapasitas fungsional, dan kualitas hidup.

Penurunan fungsi paru pada penderita asma bronkial dapat dinilai dari penurunan volume ekspirasi paksa pada detik pertama atau forced expiratory volume in 1 second $\left(\mathrm{FEV}_{\mathrm{p}}\right)$ Selain itu, karena terjadi gangguan fungsi paru yang bersifat kronik pada penderita asma alergi, kemungkinan dapat terjadi juga penurunan aktivitas seharihari yang dapat dinilai dengan jarak tempuh uji jalan 6 menit dan penurunan kualitas hidup yang dapat diprediksi dari hasil kuesioner St George's Respiratory Questionnaire (SGRQ). Penurunan fungsi paru dan kualitas hidup penderita asma bronkial erat kaitannya dengan penurunan fungsi otot yang ditandai dengan penurunan massa otot. Penurunan fungsi otot tersebut ditemukan pada otot inspirasi dan ekspirasi.

Bila kita mengamati perubahan patofisiologi pada penderita asma bronkial, maka diupayakan bermacam cara untuk menurunkan eksaserbasi asma bronkial, antara lain dengan cara pemberian rehabilitasi paru melalui latihan, pengobatan, dan lain-lain. Untuk meningkatkan fungsi otot pada umumnya dan juga otot respirasi pada khususnya serta fungsi paru dan kualitas hidup penderita asma bronkial, maka sebaiknya diberikan latihan pernapasan diafragma dan incentive spirometry. ${ }^{3-5}$

Latihan pernapasan diafragma dilaksanakan dengan merelaksasikan dada bagian atas, lengan dan bahu, tangan penderita berada pada abdomen bagian atas. Penderita diminta untuk melakukan inspirasi dan ekspirasi yang menyebabkan tangan tersebut bergerak naik dan turun.

Bentuk latihan lainnya untuk meningkatkan fungsi paru dan kualitas hidup adalah latihan menggunakan incentive spirometry. Latihan ini merupakan latihan pernapasan dengan beban yang bertujuan untuk melatih kekuatan otot inspirasi. Pada latihan ini penderita melakukan inspirasi yang maksimal dengan memakai menarik napas panjang, dalam, serta perlahan. Alat ini mudah untuk diajarkan dan dipergunakan oleh penderita tanpa supervisi, selain itu alat ini mudah untuk dibawa sehingga penderita dapat berlatih dengan frekuensi sesering-seringnya. Penggunaan alat ini dapat membantu mengukur dan memonitor volume inspirasi. Alat ini sangat bermanfaat untuk mengukur secara objektif kemampuan inspirasi maksimal yang dapat dicapai oleh penderita. ${ }^{6}$

Latihan incentive spirometry selama 4 minggu pada penderita asma bronkial di Malaysia, dapat meningkatkan $\mathrm{FEV}_{1}{ }^{4}$ Pada penelitian di Malaysia tersebut dilakukan dengan memakai incentive spirometry tipe flowmetry, hasil pengukuran dikonversi dengan cara tertentu sehingga risiko nilai pengukuran volume inspirasi maksimal itu kurang akurat. Penelitian ini dilakukan dengan menggunakan incentive spirometry tipe volumetry dan hasil pengukuran volume inspirasi maksimal dapat dinilai langsung sehingga lebih akurat.

Mengamati kedua bentuk latihan ini, dalam pelaksanaannya kemungkinan memberi pengaruh berbeda pada fungsi paru, kapasitas fungsional, dan kualitas hidup. Sampai saat ini belum ada laporan yang membandingkan efektivitas kedua 
bentuk latihan ini terhadap perbaikan penyakit asma bronkial, yang sudah memberikan hasil yang bermakna pada penderita PPOK. ${ }^{7-9}$ Tujuan penelitian ini untuk mengetahui perbandingan efektivitas latihan incentive spirometry dengan latihan pernapasan diafragma terhadap $\mathrm{FEV}$, jarak tempuh uji jalan 6 (enam) menit, dan SGRQ penderita asma bronkial alergi.

\section{Metode}

Studi intervensional dengan rancangan kuantitatif memakai metode kuasi eksperimental dengan pengamatan sebelum dan sesudah perlakuan (pre dan post test design). Pada penelitian ini terdapat dua kelompok perlakuan yaitu kelompok I adalah kelompok subjek penelitian yang diberi latihan incentive spirometry dan kelompok II adalah kelompok subjek penelitian yang diberi latihan pernapasan diafragma. Subjek penelitian adalah penderita asma bronkial alergi yang berobat ke Rumah Sakit Dr. Hasan Sadikin dan Rumah Sakit Paru Dr. H. A. Rotinsulu Bandung periode September-Desember 2012.

Populasi terjangkau penelitian ini memenuhi kriteria inklusi yaitu penderita asma bronkial alergi (tes $\operatorname{IgE}>100 \mathrm{IU} / \mathrm{mL}$ ), terkontrol sebagian, berjenis kelamin perempuan berusia 26-40 tahun dengan reversibilitas tes bronkodilator $>12 \%$, tidak merokok, tidak dalam serangan, belum pernah mengikuti latihan asma, dengan saturasi oksigen sebelum uji jalan 6 menit $\geq 95 \%$, serta mempergunakan obat inhalasi yang diresepkan oleh dokter, tidak sedang mempergunakan obat oral atau intravena. Kriteria eksklusi yaitu subjek penelitian mempunyai penyakit kardiovaskular, diabetes melitus atau penyakit paru lain, dan bila tidak mengikuti latihan 2 kali berturut-turut dalam satu hari. Jumlah subjek penelitian berdasarkan perhitungan ukuran sampel minimal dan dipilih secara acak.

Dilakukan anamnesis terhadap setiap subjek yang masuk dalam kriteria inklusi penelitian, lalu subjek diberi penjelasan mengenai maksud dan tujuan penelitian tersebut dan cara melakukan latihan di rumah sampai subjek paham dan dapat melakukannya, Semua subjek menandatangani formulir persetujuan, lalu dilakukan pemeriksaan nadi, tekanan darah, saturasi oksigen, dan juga pemeriksaan fisis lainnya untuk mendapatkan data dasar, kemudian dilakukan pemeriksaan asma alergi yaitu IgE yang diambil dari vena perifer, tes reversibilitas bronkodilator, pengisian kuisioner SGRQ, pemeriksaan jarak tempuh uji jalan 6 menit dan FEV pada setiap subjek penelitian. Subjek penelitian dibagi 2 kelompok yaitu kelompok yang diberikan perlakuan latihan dengan alat volumetric incentive spirometry dan latihan pernapasan diafragma, pelaksanaannya dilakukan di rumah subjek penelitian selama 8 minggu, sebanyak 5 kali setiap hari, setiap latihan dilakukan 10 set dan diantara set istirahat 15 detik. Alat volumetric incentive spirometry ini tidak perlu ditera karena alat ini merupakan alat untuk latihan otot pernapasan bukan merupakan alat pemeriksaan.

Cara latihan dengan alat volumetric incentive spirometry yaitu subjek penelitian agar duduk dalam posisi tegak, alat volumetric incentive spirometry dipegang dengan salah satu tangan pada posisi berdiri tegak, letakkan mouthpiece ke dalam mulut di antara gigi dengan bibir terkatup rapat-rapat mengelilingi mouthpiece, lakukan napas biasa 3 kali, tarik napas sekuatnya dengan bibir terkatup rapat-rapat mengelilingi mouthpiece dan ditahan selama 3-5 detik, sesuai toleransi penderita. Usahakan indikator piston bergerak setinggi-tingginya semampu penderita (menunjukkan jumlah volume inspirasi yang dapat dicapai), bagian atas dari indikator kuning (bola kuning) harus berada pada posisi kotak tersenyum, setelah itu lakukan buang napas (ekspirasi) perlahan-lahan, lepaskan mouthpiece dari mulut dan dianjurkan untuk batuk setelah menyelesaikan latihan. Latihan dapat dihentikan jika terasa pusing dan sesak. Latihan dilakukan setiap hari di rumah $5 x /$ hari, dengan 10 set, di antaranya istirahat selama 15 detik. Catat waktu dan jumlah volume maksimal serta ditandatangani penderita dan saksi setiap kali melakukan latihan pada buku monitoring harian.

Cara melakukan latihan pernapasan diafragma yaitu subjek penelitian duduk dalam posisi tegak, posisi kepala agak menunduk, letakkan tangan kanan pada perut di atas perut (abdomen)/pusat (umbilikus) dan tangan kiri pada dada (toraks) untuk panduan mengenali gerakan pada iga yang membatasi pernapasan diafragma, tarik napas sekuat-kuatnya melalui hidung, lalu tahan selama 3-5 detik, sesuai toleransi penderita, selanjutnya keluarkan napas perlahan dengan menghembus melalui mulut yang akan mendorong perut ke dalam dan ke atas, gerakan tangan menunjukkan penderita telah melakukan latihan dengan benar atau tidak yaitu apabila tangan di atas perut (abdomen) bergerak selama inspirasi, penderita sudah bekerja dengan benar, dan apabila tangan pada dada (toraks) bergerak, berarti penderita menggunakan otot-otot dada (toraks), selanjutnya dilatih untuk melakukan ekspirasi panjang tanpa kehilangan kontrol agar inspirasi yang berikutnya tanpa terengah-engah (gasping)/gerakan dada atas. Latihan dapat dihentikan jika terasa pusing dan sesak. Latihan dilakukan setiap hari di rumah $5 \mathrm{x} /$ hari, sebanyak 10 set, di antaranya istirahat 
15 detik. Catat waktu dan ditandatangani oleh penderita dan saksi setiap kali melakukan latihan pada buku catatan harian.

Monitoring dilakukan setiap hari per telepon, sedangkan kunjungan rumah dilakukan setiap minggu (pada saat kunjungan rumah peneliti/ fisioterapis selalu mengamati pelaksanaan latihan subjek penelitian). Setiap minggu catatan harian latihan yang dilakukan dimonitor disertai dengan tanda tangan saksi dan subjek penelitian.

Evaluasi kedua dilakukan setelah menjalani 8 minggulatihan, dilakukan pemeriksaan spirometry (untuk mengukur FEV,), uji jalan 6 menit (untuk mengukur kapasitas fungsional), dan ditanyakan kembali kuesioner SGRQ (untuk menilai kualitas hidup). Selama menjalani rangkaian penelitian, penderita diberikan dukungan, motivasi untuk mengikuti latihan sampai selesai, edukasi tentang penyakitnya, obat-obatan yang diresepkan tetap digunakan, dan saran asupan makanan seharihari.

Data hasil penelitian ini diolah dengan cara komputerisasi untuk dapat mengubah data menjadi informasi, dengan langkah-langkah editing yaitu memeriksa kebenaran data yang akan diperlukan, coding yaitu mengubah data berbentuk kalimat atau huruf menjadi data angka atau bilangan, data entry yaitu memasukkan data, yakni hasil pemeriksaan dan pengukuran subjek penelitian yang telah di-coding, dimasukkan ke dalam suatu program komputer, serta cleaning apabila semua data responden telah selesai dimasukkan, maka perlu dicek kembali untuk melihat kemungkinan kesalahan pengkodean, ketidaklengkapan, dan sebagainya, kemudian dilakukan koreksi.

Rancangan analisis data penelitian diawali dengan melakukan Uji normalitas KolmogorofSmirnof $(p>0,05)$ untuk dapat mengetahui hasil penelitian rata-rata apakah berdistribusi normal atau tidak normal. Hasil uji normalitas untuk menentukan analisis berikutnya, apakah analisis parametrik apabila data tersebut berdistribusi normal atau analisis nonparametrik apabila data tidak berdistribusi normal. Setelah itu dilakukan uji homogenitas kelompok dengan Uji Levene $(\mathrm{p}>0,05)$ untuk mengetahui apakah varian data pengukuran antara kelompok tersebut homogen atau tidak. Tahap yang berikutnya dipergunakan uji-t dependen $(\mathrm{p}<0,05)$ untuk menguji pengaruh latihan pernapasan diafragma dan latihan incentive spirometry pada fungsi paru, kapasitas fungsional, dan kualitas hidup penderita asma bronkial. Uji-t independen $(p<0,05)$ untuk menguji perbandingan efektivitas latihan pernapasan diafragma dengan latihan incentive spirometry terhadap fungsi paru, kapasitas fungsional, dan kualitas hidup pada penderita asma bronkial. Seluruh pekerjaan data menggunakan program SPSS for Windows versi
13.0.

Penelitian melibatkan subjek manusia, karena itu kemungkinan dapat timbul masalah etik. Aspek etik ini adalah masalah ketidaknyamanan yang mungkin muncul ketika dilakukan intervensi, serta biaya yang timbul karena intervensi tersebut. Hal ini dapat diatasi dengan memberikan konseling tentang kegunaan penelitian tersebut serta subjek mendapatkan efek terapi terhadap keluhan secara langsung. Setiap informasi dan data penelitian ini akan diperlakukan secara rahasia. Seluruh pembiayaan yang terkait dengan penelitian ini ditanggung oleh peneliti.

Penelitian ini dilaksanakan sesudah subjek penelitian diberi informasi dan dengan prinsip sukarela serta persetujuan yang diperoleh dengan menandatangani formulir persetujuan mengikuti penelitian (informed consent) dan telah mendapat persetujuan Komite Etik Penelitian Kesehatan Fakultas Kedokteran Unpad/Rumah Sakit Dr. Hasan Sadikin (RSHS) Bandung.

\section{Hasil}

Jumlah sampel penelitian yang minimal setelah ditambah dengan faktor non respons atau drop out, didapatkan jumlah sampel 10 orang untuk tiap kelompok, sehingga jumlah sampel 20 orang.

Karakteristik subjek penelitian ini, terdiri atas usia (tahun), body mass index (BMI) $\left(\mathrm{kg} / \mathrm{cm}^{2}\right)$, reversibilitas (\%), kuesioner asthma control test $(\mathrm{ACT}), \operatorname{IgE}(\mathrm{IU} / \mathrm{mL})$, pekerjaan, pendidikan, perawatan selama di rumah sakit, penggunaan bronkodilator, kortikosteroid inhalasi pada latihan incentive spirometry, dan pernapasan diafragma.

Untuk mengetahui homogenitas karakteristik subjek penelitian sebelum perlakuan (Tabel 1) dilakukan uji-t independen untuk data ordinal dan uji chi-kuadrat untuk data nominal $(\mathrm{p} \geq 0,05)$. Hasil analisis menunjukkan bahwa karakteristik kedua kelompok subjek penelitian relatif homogen.

Uji Shapiro Wilks $(\mathrm{p} \geq 0,05)$ memperlihatkan bahwa sebagian besar data $\mathrm{FEV}_{1}$, jarak tempuh uji jalan 6 menit, dan SGRQ penderita asma bronkial alergi yang diberi latihan incentive spirometry dan pernapasan diafragma berdistribusi normal. Uji homogenitas dengan Levene's test for equality of varians $(\mathrm{p} \geq 0,05)$, hasilnya menunjukkan bahwa data $\mathrm{FEV}_{1}$, jarak tempuh uji jalan 6 menit, dan SGRQ penderita asma bronkial yang diberikan latihan incentive spirometry dan pernapasan diafragma adalah homogen. Uji normalitas dan homogenitas (Tabel 2) dilakukan terhadap hasil pengukuran $\mathrm{FEV}_{1}$, jarak tempuh uji jalan 6 menit, dan SGRQ penderita asma bronkial alergi setelah diberi perlakuan latihan incentive spirometry dan pernapasan diafragma. 
Sitti Nurun N.: Efektivitas Latihan Incentive Spirometry dengan Latihan Pernapasan Diafragma

Tabel 1 Karakteristik Penderita Asma Bronkial Alergi

\begin{tabular}{|c|c|c|c|c|c|}
\hline \multirow[b]{2}{*}{ Variabel } & \multicolumn{4}{|c|}{ Kelompok } & \multirow[b]{2}{*}{$\mathbf{p}$} \\
\hline & $\mathbf{n}$ & $\begin{array}{c}\text { Incentive Spirometry } \\
\text { (Rata-rata } \pm \text { SD) }\end{array}$ & $\mathbf{n}$ & $\begin{array}{c}\text { Pernapasan Diafragma } \\
\text { (Rata-rata } \pm \text { SD) }\end{array}$ & \\
\hline Usia (tahun) & & $32,90 \pm 5,38$ & & $32,40 \pm 5,83$ & $\left.0,844^{*}\right)$ \\
\hline BMI & & $22,48 \pm 3,16$ & & $21,69 \pm 2,36$ & $0,534 *)$ \\
\hline Reversibilitas & & $8,55 \pm 4,30$ & & $26,36 \pm 9,22$ & $0,031 *)$ \\
\hline $\mathrm{ACT}$ & & $21,00 \pm 0,81$ & & $21,00 \pm 0,94$ & $\left.1,000^{*}\right)$ \\
\hline $\operatorname{IgE}$ & & $401,81 \pm 105,73$ & & $683,06 \pm 329,18$ & $\left.0,026^{*}\right)$ \\
\hline Pekerjaan & & & & & $\left.0,219^{* *}\right)$ \\
\hline PNS & 0 & & 3 & & \\
\hline Wiraswasta & 0 & & 1 & & \\
\hline Dokter gigi & 0 & & 1 & & \\
\hline Mahasiswa S-1 & 0 & & 1 & & \\
\hline Buruh pabrik & 5 & & 3 & & \\
\hline Mahasiswa S-2 & 1 & & 0 & & \\
\hline Konsultan & 1 & & 0 & & \\
\hline IRT & 3 & & 1 & & \\
\hline Pendidikan & & & & & $1,000 * *)$ \\
\hline Tamat SMA & 2 & & 2 & & \\
\hline Tamat Akademi & 3 & & 3 & & \\
\hline Tamat Universitas & 5 & & 5 & & \\
\hline Perawatan di rumah sakit & & & & & $1,000 * *)$ \\
\hline $\mathrm{Ya}$ & 4 & & 4 & & \\
\hline Tidak & 6 & & 6 & & \\
\hline $\begin{array}{l}\text { Penggunaan bronkodilator } \\
\text { inhalasi }\end{array}$ & & & & & $1,000 * *)$ \\
\hline $\mathrm{Ya}$ & 7 & & 7 & & \\
\hline Tidak & 3 & & 3 & & \\
\hline $\begin{array}{l}\text { Penggunaan kortikosteroid } \\
\text { inhalasi }\end{array}$ & & & & & $0,5000 * *)$ \\
\hline $\mathrm{Ya}$ & 6 & & 7 & & \\
\hline Tidak & 4 & & 3 & & \\
\hline
\end{tabular}

Keterangan: *)Pengujian menggunakan uji-t independen, ${ }^{* *}$ ) Pengujian menggunakan uji chi-kuadrat, BMI: body mass index, ACT: asthma control test, IgE: Imunoglobulin E, PNS: pegawai negeri sipil, IRT: ibu rumah tangga

Untuk mengetahui efektivitas antara latihan incentive spirometry dan pernapasan diafragma terhadap $F E V_{1}$ pada penderita asma bronkial alergi dilakukan uji-t independen $(\mathrm{p}=0,000)$ hasilnya menunjukkan bahwa latihan incentive spirometry lebih efektif meningkatkan FEV dibandingkan dengan pernapasan diafragma (Tabel 3). Untuk dapat mengetahui perbandingan efektivitas antara incentive spirometry dan pernapasan diafragma terhadap jarak tempuh uji jalan 6 menit pada penderita asma bronkial alergi dipergunakan uji-t independen $\mathrm{p}=0,000 \quad(\mathrm{p}<0,05)$. Hasilnya menunjukkan bahwa latihan incentive spirometry lebih efektif meningkatkan jarak tempuh uji jalan 6 menit dibandingkan dengan pernapasan diafragma (Tabel 3). Untuk dapat mengetahui perbandingan efektivitas antara latihan incentive spirometry dan pernapasan diafragma terhadap $S t$ George's Respiratory Questionnaire/SGRQ pada penderita asma bronkial alergi dipergunakan uji- $t$ independen $(p=0,000 ; p<0,05)$. Hasilnya menunjukkan latihan incentive spirometry lebih 
Sitti Nurun N.: Efektivitas Latihan Incentive Spirometry dengan Latihan Pernapasan Diafragma

Tabel 2 Uji Normalitas dan Homogenitas Penderita Asma Bronkial Alergi setelah Diberi Latihan Incentive Spirometry dan Pernapasan Diafragma

\begin{tabular}{|c|c|c|c|c|c|c|}
\hline \multirow{3}{*}{ Variabel } & \multicolumn{4}{|c|}{ Uji Normalitas Data } & \multirow{2}{*}{\multicolumn{2}{|c|}{ Uji Homogenitas }} \\
\hline & \multicolumn{2}{|c|}{$\begin{array}{l}\text { Latihan Incentive } \\
\text { Spirometry }(\mathrm{n}=10)\end{array}$} & \multicolumn{2}{|c|}{$\begin{array}{l}\text { Latihan Pernapasan } \\
\text { Diafragma }(n=10)\end{array}$} & & \\
\hline & $\mathbf{p}$ & Distribusi & $\mathbf{p}$ & Distribusi & $\mathrm{p}$ & Homegenitas \\
\hline Perubahan FEV1 & $\left.0,349^{*}\right)$ & Normal & $0,001 *)$ & Normal & $0,990 * *)$ & Homogen \\
\hline $\begin{array}{l}\text { Perubahan jarak tempuh } \\
\text { uji jalan } 6 \text { menit }\end{array}$ & $\left.0,058^{*}\right)$ & Normal & $\left.0,120^{*}\right)$ & Normal & $0,064 * *)$ & Homogen \\
\hline Perubahan SGRQ & $\left.0,238^{*}\right)$ & Normal & $\left.0,346^{*}\right)$ & Normal & $0,519 * *)$ & Homogen \\
\hline
\end{tabular}

Keterangan: *) Pengujian menggunakan Uji Shapiro Wilks, **) Pengujian menggunakan Uji Levene

efektif memperbaiki SGRQ bila dibandingkan dengan pernapasan diafragma (Tabel 3).

\section{Pembahasan}

Latihan incentive spirometry lebih efektif untuk meningkatkan $\mathrm{FEV}_{1}$ bila dibandingkan dengan pernapasan diafragma dengan uji-t independen $\mathrm{p}=0,000 \quad(6,19 \pm 2,63$ vs $0,40 \pm 0,33 \%$ prediksi $)$ berdasarkan hasil penelitian ini, karena latihan incentive spirometry meningkatkan kemampuan inspirasi yangmaksimal.Peningkatankemampuan inspirasi terjadi oleh karena pada saat inspirasi

Tabel 3 Perbandingan Efektivitas antara Latihan Incentive Spirometry dengan Pernapasan Diafragma terhadap FEV1, Jarak Tempuh Uji Jalan 6 Menit, SGRQ pada Penderita Asma Bronkial Alergi

\begin{tabular}{|c|c|c|c|}
\hline \multirow[b]{2}{*}{ Variabel } & \multicolumn{2}{|c|}{ Perlakuan } & \multirow[b]{2}{*}{ p *) } \\
\hline & $\begin{array}{c}\text { Incentive Spirometry }(\mathrm{n}=10) \\
\text { (Rata-rata } \pm \text { SD) }\end{array}$ & $\begin{array}{c}\text { Pernapasan Diafragma }(n=10) \\
\text { (Rata-rata } \pm \text { SD) }\end{array}$ & \\
\hline \multicolumn{4}{|l|}{ FEV1 } \\
\hline Pretes & $67,93 \pm 3,47$ & $66,66 \pm 6,43$ & 0,590 \\
\hline Postest & $74,12 \pm 4,42$ & $67,06 \pm 5,32$ & 0,005 \\
\hline Paired t-test & 0,000 & 0,000 & \\
\hline Beda pre dan postes & $-6,19 \pm 2,63$ & $-0,40 \pm 0,33$ & 0,000 \\
\hline Persentase perubahan & $-9,13 \pm 3,82$ & $-0,75 \pm 0,11$ & 0,000 \\
\hline \multicolumn{4}{|l|}{$\begin{array}{l}\text { Jarak tempuh uji jalan } \\
6 \text { menit }\end{array}$} \\
\hline Pretes & $252,16 \pm 21,86$ & $228,46 \pm 9,93$ & 0,066 \\
\hline Postes & $481,24 \pm 33,23$ & $369,15 \pm 21,23$ & 0,000 \\
\hline Paired t-test & 0,000 & 0,000 & \\
\hline Beda pre dengan postes & $-229,07 \pm 21,84$ & $-140,69 \pm 16,91$ & 0,000 \\
\hline Persentase perubahan & $-91,33 \pm 10,32$ & $-61,63 \pm 7,40$ & 0,000 \\
\hline \multicolumn{4}{|l|}{ SGRQ } \\
\hline Pretes & $1.702,96 \pm 521,79$ & $1.481,88 \pm 713,62$ & 0,430 \\
\hline Postes & $666,45 \pm 305,00$ & $1.121,79 \pm 605,72$ & 0,048 \\
\hline Paired t-test & 0,000 & 0,000 & \\
\hline Beda pre dengan postes & $1.036,51 \pm 341,14$ & $360,09 \pm 182,10$ & 0,000 \\
\hline Persentase perubahan & $61,39 \pm 13,74$ & $27,88 \pm 14,17$ & 0,000 \\
\hline
\end{tabular}

Keterangan: *) Pengujian menggunakan uji-t independen 
panjang, dalam, dan perlahan disertai dengan bibir terkatup rapat mengelilingi mouthpiece sambil ditahan 3 sampai 5 detik. Peningkatan kemampuan inspirasi maksimal terjadi pula karena latihan ini mempergunakan beban, sehingga pada saat inspirasi penderita dipaksa untuk meningkatkan kekuatan otot inspirasi secara maksimal dengan mengusahakan agar indikator piston bergerak setinggi-tingginya dan semampu penderita. Pada keadaan tersebut akan tercapai volume inspirasi maksimal. Indikator bola kuning harus berada terhadap posisi indikator tertentu dan penderita mempertahankan volume inspirasi semaksimalmaksimalnya. Kekuatan otot-otot inspirasi yang meningkat tersebut berpengaruh pada elastisitas rekoil paru yang akan merangsang fungsi paru kembali seperti semula dengan meningkatkan tekanan transpulmonal dan volume paru pada saat inspirasi. Proses ini mampu memperbaiki efisiensi napas yang akan menurunkan derajat sesak. Alat ini juga dapat memberikan efek umpan balik visual secara nyata yang akan mendorong penderita untuk meningkatkan volume inspirasi semaksimal-maksimalnya. ${ }^{6,10}$

Volume paru-paru yang meningkat setelah inspirasi maksimal akan mampu meningkatkan jumlah udara yang dapat dikeluarkan secara paksa di dalam detik pertama sesudah inspirasi maksimal, sehingga nilai FEV, meningkat. Nilai $\mathrm{FEV}_{1}$ dihitung dalam satuan $\mathrm{L}$ atau \% prediksi yang memperlihatkan persentase kapasitas vital. Nilai FEV 1 ini merupakan pemeriksaan fungsi paru yang objektif untuk menentukan derajat obstruksi jalan napas. ${ }^{1,8}$ Proses yang terjadi saat melakukan latihan incentive spirometry yang dapat meningkatkan fungsi paru (FEV) tidak ditemukan saat melakukan pernapasan diafragma. Hasil yang ditemukan pada penelitian ini sesuai dengan penelitian yang dilakukan di Malaysia selama 4 minggu dengan menggunakan latihan incentive spirometry yang meningkatkan $\mathrm{FEV}_{1}$ sebesar 2,38 L. ${ }^{4}$ Terdapat perbedaan alat incentive spirometry yang digunakan di Malaysia dengan yang dipergunakan peneliti, yaitu di Malaysia mempergunakan alat incentive spirometry tipe flowmetry, sedangkan yang digunakan peneliti tipe volumetry. ${ }^{4}$ Pada penelitian di Malaysia dengan alat incentive spirometry tipe flowmetry, hasil pengukuran dikonversi dengan perhitungan tertentu sehingga risiko nilai pengukuran volume inspirasi maksimal kurang akurat. Pada penelitian ini dilakukan dengan menggunakan incentive spirometry tipe volumetry dan hasil pengukuran volume inspirasi maksimal dapat dinilai langsung sehingga lebih akurat. Dari uraian di atas dapat menunjukkan latihan incentive spirometry lebih efektif untuk meningkatkan fungsi paru $\left(\mathrm{FEV}_{1}\right)$ bila dibandingkan dengan pernapasan diafragma.
Penelitian pada penderita asma bronkial memakai alat yang sama dengan peneliti menggunakan parameter fungsi paru $\left(\mathrm{FEV}_{1}\right)$ belum ditemukan.

Latihan incentive spirometry lebih efektif meningkatkan jarak tempuh uji jalan 6 (enam) menit apabila dibandingkan dengan pernapasan diafragma, dengan uji-t independen $\mathrm{p}=0,000$ $(229,07 \pm 21,84$ vs $140,69 \pm 16,91 \mathrm{~m})$, oleh karena latihan incentive spirometry dapat meningkatkan kekuatan otot inspirasi dan juga volume paru setelah inspirasi maksimal. Keadaan ini akan berpengaruh pada elastisitas rekoil paru sehingga dapat memperbaiki efisiensi napas sehingga menurunkan derajat sesak yang kemudian dapat meningkatkan aktivitas kehidupan sehari-hari. Oleh karena latihan incentive spirometry dapat meningkatkan fungsi paru, maka asupan oksigen pada saat inspirasi akan meningkat, perfusi oksigen dari alveoli menuju hemoglobin dan daya tangkap hemoglobin juga meningkat oleh karena dengan latihan akan meningkatkan enzim oksidatif, dan daya tangkap mioglobin terhadap oksigen. Keadaan inilah yang dapat menjelaskan latihan incentive spirometry dapat meningkatkan kapasitas fungsional penderita asma bronkial alergi. Terjadi peningkatan kapasitas fungsional yang dapat diukur dengan jarak tempuh uji jalan 6 menit. Pada latihan pernapasan diafragma oleh karena intensitas latihan tidak cukup kuat untuk merangsang fungsi paru, sehingga asupan oksigen dan difusi oksigen relatiflebih rendah pada latihan pernapasan diafragma bila dibandingkan dengan incentive spirometry. Dari uraian di atas dapat menjelaskan latihan incentive spirometry lebih efektif meningkatkan kapasitas fungsional (jarak tempuh uji jalan 6 menit) dibandingkan dengan pernapasan diafragma. Untuk penelitian pada penderita asma bronkial dengan menggunakan alat yang sama dengan peneliti dengan parameter kapasitas fungsional (jarak tempuh uji jalan 6 menit) belum ditemukan.

Latihan incentive spirometry lebih efektif untuk memperbaiki SGRQ dibandingkan dengan pernapasan diafragma dengan uji-t independen $\mathrm{p}=0,000$ (nilai total terhadap gejala, dampak, dan aktivitas $(1.036,51 \pm 341,14$ vs $360,09 \pm 182,10)$ oleh karena latihan incentive spirometry dapat meningkatkan kekuatan otot inspirasi dan volume paru, yang akan memperbaiki efisiensi napas dan menurunkan derajat sesak sehingga dapat memperbaiki aktivitas sehari-hari yang secara keseluruhan memperbaiki kualitas hidup yang berhubungan dengan penyakit asma bronkial alergi. Peningkatan kualitas tersebut tercermin dari gejala sesak napas yang berkurang, batuk yang berkurang, dan juga serangan asma yang menurun. Selain itu, terdapat perbaikan aktivitas sehari-hari yang meningkat dan dampak negatif 
terhadap pekerjaan berkurang, gejala, obat-obatan yang digunakan serta aktivitas dan kehidupan sehari-hari menjadi lebih baik. ${ }^{11,12}$ Dari hasil penelitian ternyata jarak tempuh uji jalan 6 menit berkorelasi positif dengan kualitas hidup. ${ }^{11,12}$ Dengan latihan incentive spirometry selain dapat meningkatkan kekuatan otot inspirasi secara maksimal, juga mampu membantu pengeluaran dahak, sehingga efisiensi napas dapat diperbaiki dan juga mengurangi sesak yang berdampak pada perbaikan kualitas hidup. Perbaikan ini akan meningkatkan asupan dan perfusi oksigen ke dalam darah.

Kualitas hidup merupakan kebahagiaan dan kepuasan terpenting kehidupan manusia, serta merupakan indikator objektif kesejahteraan materi dan sumber daya individu. Kualitas hidup seorang yang sakit akan memengaruhi status kesehatan dan berdampak pada status fungsional dalam melakukan aktivitas sehari-hari. Pada penderita asma bronkial alergi, kualitas hidup merupakan suatu ukuran penting, karena berhubungan erat dengan kondisi sesak yang sangat mengganggu penderita dalam melakukan aktivitas sehari-hari (kapasitas fungsional) seperti berjalan, merawat diri, berpakaian, makan, dan aktivitas rumah tangga. Pengukuran kualitas hidup sangat penting dalam menilai respons/efek terapi. Dalam jangka panjang efek terapi latihan bermanfaat terhadap penurunan gejala, peningkatan aktivitas seharihari, serta rasa percaya diri yang lebih besar. $S t$ George's Respiratory Questionnaire merupakan kuisioner spesifik untuk mengukur kualitas hidup pada penderita saluran napas kronik yaitu asma bronkial dan PPOK. Kuesioner ini terdiri atas tiga komponen utama yaitu gejala penyakit (symptoms) yang berhubungan dengan gejala saluran napas, frekuensi dan hebatnya gejala tersebut, aktivitas (activity) yang berhubungan dengan aktivitas yang menyebabkan sesak atau dihambat oleh sesak, dan dampak (impacts) yang meliputi serangkaian aspek yang berhubungan dengan fungsi sosial dan gangguan psikologis oleh karena penyakit jalan napas. Setiap butir pertanyaan dalam kuesioner SGRQ mempunyai keterkaitan kuat dengan gejala dan keadaan sesak yang dialami penderita.

Oleh karena pola bentuk latihan incentive spirometry memberikan intensitas beban latihan yang lebih besar dibandingkan dengan pernapasan diafragma, sebagaimana diuraikan sebelumnya memberikan pengaruh yang berbeda pada fungsi paru $\left(\mathrm{FEV}_{1}\right)$ dan kapasitas fungsional. Ternyata dari hasil penelitian perbedaan intensitas kedua latihan ini memberikan pengaruh yang berbeda pula pada kualitas hidup (SGRQ).

Uraian di atas dapat menjelaskan latihan incentive spirometry lebih efektif dibandingkan dengan pernapasan diafragma dan bermanfaat serta banyak digunakan pada penderita dengan gangguan jalan napas kronik antara lain asma bronkial alergi. $4,7-9,13,14$

Sebagai simpulan, latihan incentive spirometry lebih efektif meningkatkan fungsi paru $\left(\mathrm{FEV}_{1}\right)$, meningkatkan kapasitas fungsional (jarak tempuh uji jalan enam menit), dan memperbaiki kualitas hidup (memperbaiki SGRQ) bila dibandingkan dengan pernapasan diafragma pada penderita asma bronkial alergi.

\section{Daftar Pustaka}

1. Bateman ED, Boulet LP, Cruz A, FitzGerald M, Haahtela, Levy M, dkk. Global initiative for asthma. Global strategy for asthma management and prevention. Update 2011. South Africa: GINA. 2011.

2. Eizadi M, Shafiei M, Rohani AA, Jenabi A. Exercise as a none-pharmalogicel intervention in maintain $\operatorname{IgE}$ in asthma patients. Indian J Fundamental Applied Life Sci. 2011;1(4):371-5.

3. Thomas M, McKinley RK, Mellor S, Watkin G, Holloway E, Scullion J, dkk. Breathing exercises for asthma: a randomized controlled trial. Thorax. 2009;64(1):55-61.

4. Loh LC, Puah SH, Ho CV, Chow CY, Chua CY, Jayaram J, dkk. Disability and breathlessness in asthmatic patients - a scoring method by repetitive inspiratory effort. Asthma. 2005;42(10):853-8.

5. Turner LA, Mickleborough TD, McConnel AK, Stager JM, Tecklenburg-Lund S, Lindley MR. Effect of inspiratory muscle training on exercise tolerance in asthmatic individuals. Med Sci Sports Exerc. 2011;43(11):2031-8.

6. Hill K, Cecins NM, Eastwood PR, Jenkins SC. Inspiratory muscle training for patients with chronic obstructive pulmonary disease: a practical guide for clinicians. Arch Phys Med Rehabil. 2010;91(9):1466-70.

7. Basoglu OK, Atasever A, Bacakoglu F. The efficacy of incentive spirometry in patients with COPD. Respirology. 2005;10(3): 349-53.

8. Gosselink R, De Vos J, van den Heuvel SP, Segers J, Decramer M, Kwakkel G. Impact of inspiratory muscle training in patients with COPD: what is the evidence. Eur Respir J. 2011;37(2):416-25.

9. Tambunan TFU. Pengaruh latihan pernapasan incentive spirometry terhadap kemampuan inspirasi maksimal dan kualitas hidup pada penderita paru obstruksi kronik [tesis]. Jakarta: Universitas Indonesia; 2006. 
10. Restrepo RD, Wettstein R, Wittnebel L, Tracy M. Incentive spirometry: 2011. Respir Care. 2011;56(10):1600-4.

11. Li AM, Yin J, Yu CC, Tsang T, So HK, Wong E, dkk. The six-minute-walk test in healthy children: reliability and validity. Eur Respir J. 2005;25(6):1057-60.

12. Li AM, Yin J, Au JT, So HK, Tsang T, Wong E, dkk. Standard reference for the sixminute-walk test in healthy children aged
7 to 16 years. Am J Respir Crit Care Med. 2007:176(2):174-80.

13. Hill K, Jenkins SC, Phillippe DL, Cecins N, Shepherd KL, Green DJ, dkk. High-intensity inspiratory muscle training in COPD. Eur Respir J. 2006;27(6):1119-28.

14. Padula CA, Yeaw E. Inspiratory muscle training: integrative review. Res Theory Nurs Pract. 2006;20(4):291-304. 